\title{
Cost Effectiveness of Insulin Degludec Plus Liraglutide (IDegLira) in a Fixed Combination for Uncontrolled Type 2 Diabetes Mellitus in Sweden
}

\author{
Åsa Ericsson ${ }^{1} \cdot$ Adam Lundqvist $^{2}$
}

Published online: 6 January 2017

(c) The Author(s) 2017. This article is published with open access at Springerlink.com

\begin{abstract}
Background Patients with uncontrolled type 2 diabetes mellitus (T2DM) are a priority group for intensified therapy without weight gain and with low risk of hypoglycaemia. Objective This study evaluates the cost effectiveness of insulin degludec plus liraglutide (IDegLira, Xultophy ${ }^{\circledR}$ ) compared with six potential intensification treatment options for patients with T2DM that is uncontrolled with basal insulin. Methods The Swedish Institute for Health Economics (IHE) Cohort Model of Type 2 Diabetes was used with Swedish input data, a 40-year time frame and a societal perspective. The comparators for treatment intensification included insulin glargine, neutral protamine Hagedorn (NPH) insulin, insulin aspart plus either glargine or NPH, and liraglutide plus either glargine or NPH. Clinical data for all comparators (except NPH insulin) were based on an indirect treatment comparison of several studies. Prices were obtained from the 2014 Swedish Dental and Pharmaceutical Benefits Agency (Tandvårds- och läkemedelsförmånsverket [TLV]) database, and utility values were obtained from published studies. Sensitivity analyses were undertaken.

Results Overall incremental cost-effectiveness ratios (ICER) were Swedish krona (SEK) 70,000 or lower per quality-adjusted life-year (QALY). IDegLira compared
\end{abstract}

Electronic supplementary material The online version of this article (doi:10.1007/s40258-016-0301-y) contains supplementary material, which is available to authorized users.

Åsa Ericsson

asae@novonordisk.com

1 Novo Nordisk Scandinavia AB, Box 505, 20215 Malmö, Sweden

2 IHE, The Swedish Institute for Health Economics, Lund, Sweden with intensified basal insulin showed an ICER of SEK 28,000 per QALY versus insulin glargine, SEK70,000 per QALY versus NPH insulin and SEK 60,000 per QALY versus NPH insulin plus liraglutide. IDegLira was dominant over insulin glargine plus liraglutide and insulin aspart plus insulin glargine or NPH insulin. Results were driven by the difference in glycated haemoglobin $\left(\mathrm{HbA}_{1 \mathrm{c}}\right)$ reduction between treatments, as confirmed by sensitivity analyses.

Conclusions IDegLira is estimated to be a cost-effective treatment in Sweden compared with commonly used intensification treatments for patients with T2DM uncontrolled with basal insulin.

\section{Key Points for Decision Makers}

Insulin degludec plus liraglutide (IDegLira) is estimated to be a cost-effective treatment for patients with type 2 diabetes mellitus compared with other commonly available therapies in Sweden.

These analyses show glycaemic control is the main driver of differences in cost effectiveness between treatments.

\section{Introduction}

The overall therapeutic goal for patients with type 2 diabetes mellitus (T2DM) is to prevent acute and long-term complications while maintaining quality of life. Glycaemic control, expressed as glycated haemoglobin $\left(\mathrm{HbA}_{1 \mathrm{c}}\right)$, is a key therapeutic target because elevated $\mathrm{HbA}_{1 \mathrm{c}}$ levels are 
associated with an increased risk of complications and mortality and thus increased healthcare costs [1]. An $\mathrm{HbA}_{1 \mathrm{c}}$ of $<52 \mathrm{mmol} / \mathrm{mol}(6.9 \%)$ is a commonly stated target value [2-4]; however, in 2015, only half of the patient population with T2DM in Sweden achieved this target [5]. Swedish patients with $\mathrm{HbA}_{1 \mathrm{c}}>73 \mathrm{mmol} / \mathrm{mol}$ $(8.8 \%)$ are considered a priority group for intensified treatment, both by the Swedish National Diabetes Register (NDR) and the Swedish National Board of Health and Welfare [6, 7].

Common barriers to achieving glycaemic control include hypoglycaemia, weight gain and adherence to treatment. Hypoglycaemia can cause burdensome symptoms such as dizziness, headache, anxiety, lack of concentration and confusion $[2,8]$, which can affect the ability to work and carry out daily activities [9]. In Sweden, insulin-treated patients with T2DM have been reported to experience an average of one episode of hypoglycaemia every 2 weeks [10-12]. Severe hypoglycaemia may, in rare cases, lead to loss of consciousness or death $[2,8]$ and can incur high societal costs [13]. Weight gain is perceived as another barrier to achieving glycaemic targets [14] as it increases the risk of cardiovascular disease, mortality and impaired quality of life [15], which also lead to increased healthcare costs [16].

Simplified insulin treatment regimens may improve glycaemic control since the number of daily injections has been reported to be a major issue in adherence to diabetes treatments [17]. Treatment complexity is a common reason why patients and physicians are reluctant to intensify treatment from basal insulin alone to basal-bolus, even when such intensification is indicated for achieving glycaemic targets [18]. Basal-bolus treatment also requires frequent blood glucose tests, which may impact on treatment adherence [19].

Swedish guidelines currently recommend an intermediate-acting basal human insulin (neutral protamine Hagedorn $[\mathrm{NPH}]$ insulin; Insuman ${ }^{\circledR}$ Basal) to be routinely prescribed in T2DM, with long-acting insulin analogs (such as insulin glargine, Lantus ${ }^{\circledR}$; insulin detemir, Levemir $^{\circledR}$; insulin degludec, Tresiba ${ }^{\circledR}$ ) offered as secondline treatment or when patients experience repeated hyperglycaemic episodes [20]. Furthermore, guidelines published by the American Diabetes Association and the European Association for the Study of Diabetes also recommend that a basal-bolus regimen be offered to patients who do not adequately respond to glucagon-like peptide (GLP)-1 agonists added to basal insulin [21].

Insulin degludec plus liraglutide (IDegLira; Xultophy ${ }^{\circledR}$ ) is a new treatment for use in combination with oral glucose-lowering agents when these alone or combined with a GLP-1 receptor agonist or basal insulin do not provide adequate glycaemic control for patients with T2DM. It combines basal insulin (insulin degludec) and a GLP-1 receptor analogue (liraglutide), both of which are already included in the Swedish National reimbursement scheme for use in T2DM.

The aim of this study was to evaluate the cost effectiveness of IDegLira compared with insulin glargine $\left(\right.$ Lantus ${ }^{\circledR}$ ) and NPH insulin (Insuman ${ }^{\circledR}$ Basal) as basal insulins, insulin aspart $\left(\right.$ NovoRapid $\left.^{\circledR}\right)$ added to either insulin glargine or NPH insulin, and liraglutide (Victoza ${ }^{\circledR}$ ) added to either insulin glargine or NPH insulin, for patients with $\mathrm{T} 2 \mathrm{DM}$ whose $\mathrm{HbA}_{1 \mathrm{c}}$ is uncontrolled despite basal insulin treatment.

\section{Materials and Methods}

The Swedish Institute for Health Economics (IHE) Cohort Model of Type 2 Diabetes was used for the cost-effectiveness analyses, with Swedish data for development of complications, costs and patient benefits associated with T2DM. A 40-year perspective was used to capture all costs and effects for the remainder of the patient's life (a societal perspective, including healthcare costs and productivity losses, was used in the main analysis, and a healthcare perspective was used in the sensitivity analysis). A $3 \%$ discount rate was applied to costs and effects as per guidelines by the Swedish Dental and Pharmaceutical Benefits Agency (Tandvårds- and läkemedelsförmånsverket [TLV]) [22]. Outcomes measured in cost per qualityadjusted life-years (QALYs) were compared with the thresholds set out by the Swedish National Board of Health and Welfare to determine whether an intervention was cost effective. This board consider a cost per QALY below Swedish krona (SEK)100,000 as low, whereas incremental cost-effectiveness ratios (ICERs) between SEK100,000 and 500,000 per QALY are deemed as moderate [23]. Any assumptions used within the model were made because data were lacking; assumptions are intended to be conservative to maintain objectivity.

\subsection{Model Structure}

The model was developed by the Swedish IHE and used Markov health states to capture key microvascular and macrovascular complications and early T2DM-related death. A schematic overview of the model is presented in Fig. S1 in the Electronic Supplementary Material (ESM). It was designed in Microsoft ${ }^{\circledR}$ Excel 2013 using Visual Basic for Applications and has been externally validated as described in Lundqvist et al. [24]. The model includes multiple variables such as cohort baseline characteristics (e.g. age, sex, ethnicity, biomarkers and complications), unit costs, utility weights and choice of risk equations, with 
a treatment algorithm linked to $\mathrm{HbA}_{1 \mathrm{c}}$ defined by the user in terms of treatments used and associated expected effects $[25,26]$. Annual transition probabilities govern the progress of patients through the different simulated health states linked to, and influenced by, patient demographics, development of complications and other relevant variables.

Costs and utility weights are applied to the cohort in each annual cycle. Outcomes include the number of lifeyears, QALYs, costs, ICERs, and cumulative incidence of complications and adverse events. The model provides the option of selecting risk equations; the Swedish NDR macrovascular equations [25] and the UKPDS-OM2 (UK Prospective Diabetes Study Outcomes Model 2) mortality risk equations [26] were chosen to reflect the Swedish patient population. The model also includes separate analyses for men and women and for smokers and nonsmokers, since the risk equations for these groups differ. Non-smoking men were selected for the base-case analysis, whereas sensitivity analyses were performed for the other populations.

\subsection{Comparators and Clinical Data}

Comparators used in the cost-effectiveness analysis included a number of options for treatment intensification: uptitration of basal insulin, basal-bolus insulin and GLP-1 receptor agonist added to basal insulin. The comparators for up-titrated basal insulin were insulin glargine and NPH insulin; the comparators for basal-bolus regimens were insulin aspart added to both insulin glargine and NPH insulin; and the comparators for the GLP-1 analogue were liraglutide added to both insulin glargine and NPH insulin.

As the clinical study programme for IDegLira (Xultophy ${ }^{\circledR}$ ) has reported only two comparative studies with insulin degludec and liraglutide in patients with diabetes uncontrolled with basal insulin (DUAL ${ }^{\mathrm{TM}} \mathrm{II}$ and $\mathrm{DUAL}^{\mathrm{TM}} \mathrm{V}$ ) but none with a basal-bolus regimen or combination of GLP-1 receptor analogue and basal insulin, clinical data for the cost-effectiveness evaluation were based on an indirect treatment comparison (ITC) [27] of several studies [27-32]. For information on the ITC methodology, please see the ESM. Clinical data for all NPH insulin comparisons in the analysis were assumed to be the same as for insulin glargine, with the exception of the hypoglycaemia rates for up-titrated NPH insulin only (hypoglycaemia levels for uptitrated insulin glargine and NPH insulin were based on the results of a separate meta-analysis) [33]. Given the lack of data comparing hypoglycaemia levels between insulin glargine and NPH insulin in combination with insulin aspart or liraglutide, we conservatively assumed that these hypoglycaemia rates are the same (Table 1).

Treatment intensification was based on the assumption that treatment will be intensified when the $\mathrm{HbA}_{1 \mathrm{c}}$ level reaches $8.8 \%$. This figure represents the average $\mathrm{HbA}_{1 \mathrm{c}}$ level at which investigators in the DUAL ${ }^{\mathrm{TM}}$ II study deemed patients suitable for intensification and is in line with national treatment guidelines for diabetes that recommend patients with $\mathrm{HbA}_{1 \mathrm{c}}$ levels $>8.6 \%$ be prioritised for intensification [34]. The same $\mathrm{HbA}_{1 \mathrm{c}}$ level was used as baseline both for initiating IDegLira and for switching to basal-bolus therapy. Additionally, we assumed that patients with a blood pressure of $\geq 140 \mathrm{mmHg}$ would receive an angiotensin-converting enzyme (ACE) inhibitor (20 mg daily) as per diabetes treatment guidelines [35], which would lower blood pressure by $5 \%$, adjunct statins (40 mg daily) once their serum lipids (low-density lipoprotein [LDL]) reached $2.5 \mathrm{mmol} / \mathrm{l}$ and a fibrate once their triglycerides reached $1.7 \mathrm{mmol} / \mathrm{l}$.

Data from DUAL ${ }^{\mathrm{TM}}$ II [28] were used for baseline values for the model (Table 2). Additional baseline variables such as heart rate, white blood cells, and estimated glomerular filtration rate (eGFR) were obtained from the UKPDS-OM2 study [26]. The prevalence of cardiovascular complications (with the exception of atrial fibrillation) was obtained from the NDR cohort on which the risk equations are based (personal communication; Ali Kiadaliri, Lund University).

Efficacy endpoints were taken from the ITC [27] and only included clinical endpoints where there was a statistically significant difference between treatments. Otherwise, the comparator was assumed to be as effective as IDegLira (Table 1).

\subsection{Costs}

All costs, except drugs and consumables, are expressed as SEK, year 2013 values, and adjusted for inflation using the Swedish healthcare consumer price index yields as necessary [36] (Table S1 in the ESM). The current analysis was conducted in 2014 so we used the 2013 costing year. We acknowledge the costing year might affect the results of the analysis; however, we believe that expressing costs in SEK, year 2013 values, does not affect the results significantly because of the low inflation rate (0.7\%) [36] in 2013 in Sweden compared with 2016. Prices of drugs and consumables were obtained from the TLV price database (Table 3) [37].

The drug costs were based on pharmacy retail prices (PRPs) in September 2014, and daily doses from the clinical studies were used for IDegLira and its comparators. The price of IDegLira is billed per dose step rather than unit, which accounted for varying doses of insulin degludec and liraglutide. Doses reported by Freemantle et al. [27] were adjusted using statistical modelling to account for differences in baseline characteristics between the study cohorts. We assumed the dose of human insulin was the 
Table 1 First-year treatment efficacy based on analysis of patients with diabetes mellitus uncontrolled with basal insulin therapy [27, 32]

\begin{tabular}{|c|c|c|c|c|c|c|}
\hline & IDegLira & $\begin{array}{l}\text { Basal insulin } \\
\text { (insulin } \\
\text { glargine) }\end{array}$ & $\begin{array}{l}\text { Basal } \\
\text { insulin } \\
\text { (NPH }^{\text {insulin) }}{ }^{\mathrm{a}}\end{array}$ & $\begin{array}{l}\text { Insulin aspart }(3 \times) \text { added } \\
\text { to insulin glargine/NPH } \\
\text { insulin }^{b}\end{array}$ & $\begin{array}{l}\text { Liraglutide } 1.8 \mathrm{mg} \text { added } \\
\text { to basal insulin (insulin } \\
\text { glargine) }\end{array}$ & $\begin{array}{l}\text { Liraglutide } 1.8 \mathrm{mg} \\
\text { added to basal insulin } \\
(\mathrm{NPH} \text { insulin })^{\mathrm{c}}\end{array}$ \\
\hline$\Delta \mathrm{HbA}_{1 \mathrm{c}}(\%)$ & $\begin{array}{c}-1.66 \\
(0.07) \\
{[27]}\end{array}$ & $\begin{array}{c}-1.03 \\
(0.06)^{*}\end{array}$ & $\begin{array}{c}-1.03 \\
(0.06) \\
{[27]^{*}}\end{array}$ & $-1.33(0.07)^{*}$ & $-1.32(0.08)[27]^{*}$ & $-1.32(0.08)[27]^{*}$ \\
\hline$\Delta \mathrm{SBP}(\mathrm{mmHg})$ & $\begin{array}{c}-6.86 \\
(0.99) \\
{[27]}\end{array}$ & $\begin{array}{l}-3.49 \\
(0.75)^{*}\end{array}$ & $\begin{array}{c}-3.49 \\
(0.75) \\
{[27]^{*}}\end{array}$ & $-0.93(0.98)^{*}$ & -4.67 (1.04) [27] & -4.67 (1.04) [27] \\
\hline$\Delta \mathrm{TC}(\mathrm{mmol} / \mathrm{l})^{\mathrm{d}}$ & $\begin{array}{c}-0.26 \\
(0.06) \\
{[27]}\end{array}$ & $\begin{array}{l}-0.07 \\
\quad(0.05)^{*}\end{array}$ & $\begin{array}{c}-0.07 \\
(0.05) \\
{[27]^{*}}\end{array}$ & $0.04(0.06)^{*}$ & $-0.33(0.06)[27]$ & $-0.33(0.06)[27]$ \\
\hline$\underset{1)^{\mathrm{d}}}{\Delta \mathrm{LDL}-\mathrm{C}(\mathrm{mmol} /}$ & $\begin{array}{c}-0.18 \\
(0.05) \\
{[27]}\end{array}$ & $-0.07(0.04)$ & $\begin{array}{c}-0.07 \\
(0.04) \\
{[27]}\end{array}$ & $0.00(0.05)^{*}$ & $-0.24(0.05)[27]$ & $-0.24(0.05)[27]$ \\
\hline $\begin{array}{l}\Delta \mathrm{HDL}-\mathrm{C} \\
(\mathrm{mmol} / \mathrm{l})^{\mathrm{d}}\end{array}$ & $\begin{array}{l}0.01 \\
\quad(0.01) \\
{[27]}\end{array}$ & $0.03(0.01)$ & $\begin{array}{l}0.03(0.01) \\
{[27]}\end{array}$ & $0.02(0.01)$ & $-0.02(0.01)[27]$ & $-0.02(0.01)[27]$ \\
\hline $\begin{array}{c}\Delta \text { Triglycerides } \\
(\mathrm{mmol} / \mathrm{l})^{\mathrm{d}}\end{array}$ & $\begin{array}{c}-0.29 \\
(1.09) \\
{[27]}\end{array}$ & $\begin{array}{l}-0.03(0.07) \\
{[27]^{*}}\end{array}$ & $\begin{array}{c}-0.03 \\
(0.07) \\
{[27]^{*}}\end{array}$ & $0.04(0.09)^{*}$ & $-0.21(0.09)$ [27] & $-0.21(0.09)[27]$ \\
\hline$\Delta \mathrm{BMI}\left(\mathrm{kg} / \mathrm{m}^{2}\right)$ & $\begin{array}{c}-1.04 \\
(0.10) \\
{[27]}\end{array}$ & $\begin{array}{c}0.43(0.08) \\
{[27]^{*}}\end{array}$ & $\begin{array}{c}0.43(0.08) \\
{[27]^{*}}\end{array}$ & $1.38(0.10)^{*}$ & $-1.29(0.11)[27]$ & $-1.29(0.11)[27]$ \\
\hline $\begin{array}{l}\text { Rate of severe } \\
\text { hypoglycaemia/ } \\
100 \mathrm{PYs}\end{array}$ & 0.84 & $3.53^{\mathrm{e}}$ & $6.66^{\mathrm{e}}$ & 2.85 & Not calculated & Not calculated \\
\hline $\begin{array}{l}\text { Rate of mild } \\
\text { hypoglycaemia/ } \\
100 \text { PYs }\end{array}$ & 125.05 & $285.53 * \mathrm{e}$ & $344.01 * \mathrm{e}$ & $794.63 *$ & $124.46^{\mathrm{e}}$ & $124.46^{\mathrm{e}}$ \\
\hline
\end{tabular}

Data are presented as mean (standard error)

$\triangle$ difference operator, $B M I$ body mass index, $H b A_{I c}$ glycated haemoglobin, $H D L-C$ high-density lipoprotein cholesterol, IDegLira insulin degludec liraglutide, $L D L-C$ low-density lipoprotein cholesterol, $N P H$ neutral protamine Hagedorn, $P Y S$ patient-years, $S B P$ systolic blood pressure, $T C$ total cholesterol

* Statistically significant difference

${ }^{a}$ Clinical data regarding NPH insulin were conservatively assumed to be the same as for insulin glargine, with the exception of the hypoglycaemia rate

b As no studies have documented the difference in hypoglycaemia between insulin glargine and NPH insulin as part of a basal-bolus regimen, we made a conservative assumption that the rate of hypoglycaemia for these treatments is the same. All other clinical data regarding NPH insulin were conservatively assumed to be the same as those for insulin glargine

${ }^{c}$ Given that the clinical trials included in the indirect treatment compared IDegLira vs. liraglutide $1.8 \mathrm{mg}$, data for this dose were applied to liraglutide $1.2 \mathrm{mg}$ (more common dose in Sweden). Thus, we conservatively assumed the two doses have equivalent efficacy but only used the price of the lower dose in the base-case analysis

${ }^{\mathrm{d}}$ Cholesterol was converted from $\mathrm{mg} / \mathrm{dl}$ to $\mathrm{mmol} / \mathrm{l}$ using the formula $[\mathrm{mmol} / \mathrm{l}=(\mathrm{mg} / \mathrm{dl}) / 39]$. Triglycerides have been converted from $\mathrm{mg} / \mathrm{dl}$ to $\mathrm{mmol} / \mathrm{l}$ using the formula $[\mathrm{mmol} / \mathrm{l}=(\mathrm{mg} / \mathrm{dl}) / 89]$

e Relative difference between insulin glargine and NPH insulin with respect to hypoglycaemia [27]

same as that of insulin glargine for all treatment arms with a basal insulin when dosing once daily, given there has been no documentation of any difference in dose and NPH insulin is more likely to be administered twice daily with an associated increase in dose [38].

All patients were assumed to be using metformin $1500 \mathrm{mg}$ daily (highest tolerable dose) as an adjuvant to the study medication as per diabetes treatment guidelines [35]. Patients who received IDegLira, basal insulin or GLP1 added to basal insulin were assumed to perform one blood glucose test per day, whereas patients receiving basal-bolus regimens were assumed to perform four tests daily. The number of blood glucose tests for each comparator was based on the minimum number of daily doses 
Table 2 Baseline values of patients assigned to the IDegLira treatment arm used for the cost-effectiveness analysis from DUAL ${ }^{\mathrm{TM}}$ II (NN9068-3912) [20]

\begin{tabular}{lc}
\hline Demographics and risk factors & Mean (standard deviation) \\
\hline Age at presentation (years) & $57.2(9.7)$ \\
Duration of diabetes (years) & $10.6(6.5)$ \\
$\mathrm{HbA}_{1 \mathrm{c}}, \%$ & $8.8(0.7)$ \\
$\mathrm{SBP}(\mathrm{mmHg})$ & $132.4(15.1)$ \\
$\mathrm{TC}(\mathrm{mmol} / \mathrm{l})^{\mathrm{a}}$ & $4.67(1.21)$ \\
$\mathrm{LDL}-\mathrm{C}(\mathrm{mmol} / \mathrm{l})^{\mathrm{a}}$ & $2.58(0.96)$ \\
$\mathrm{HDL}-\mathrm{C}(\mathrm{mmol} / \mathrm{l})^{\mathrm{a}}$ & $1.16(0.31)$ \\
Triglycerides $(\mathrm{mmol} / \mathrm{l})^{\mathrm{a}}$ & $2.18(2.10)$ \\
BMI $\left(\mathrm{kg} / \mathrm{m}^{2}\right)$ & $33.7(5.7)$ \\
\hline
\end{tabular}

$B M I$ body mass index, $H b A_{l c}$ glycated haemoglobin, $H D L-C$ highdensity lipoprotein cholesterol, IDegLira insulin degludec liraglutide, $L D L-C$ low-density lipoprotein cholesterol, $T C$ total cholesterol, $S B P$ systolic blood pressure

${ }^{\text {a }}$ Cholesterol was converted from $\mathrm{mg} / \mathrm{dL}$ to $\mathrm{mmol} / \mathrm{L}$ using the formula $[\mathrm{mmol} / \mathrm{l}=(\mathrm{mg} / \mathrm{dl}) / 39]$. Triglycerides were converted from $\mathrm{mg} /$ $\mathrm{dL}$ to $\mathrm{mmol} / \mathrm{L}$ using the formula $[\mathrm{mmol} / \mathrm{l}=(\mathrm{mg} / \mathrm{dl}) / 89]$

required, i.e. one daily dose for IDegLira, basal insulin or GLP-1 added to basal insulin and four daily doses for basal-bolus insulin [35]. The unit cost of blood glucose tests (SEK2.58) was obtained by adding up the prices (PRP excluding value-added tax [VAT]) of the test strips using the lowest price per piece and the lancets using the lowest price according to the TLV price database [37].

Costs for an episode of severe hypoglycaemia were based on figures from a study by Jönsson et al. [13]. A weighted mean cost (SEK1970, year 2013 values) for each severe hypoglycaemia episode was calcualted using the conversion rate $€ 1=$ SEK9.21, August 2006 values, and adjusting for inflation. For mild hypoglycaemia, we used data from Geelhoed-duijvestijn et al. [39], which enabled calculation of the cost per mild hypoglycaemia episode at SEK50.

The costs of diabetes-related complications (e.g. heart failure, stroke, etc.) were identified from a published Swedish cost-effectiveness analysis (Table S1 in the ESM) [40] and adjusted for inflation to 2013 monetary values. The analysis also included indirect costs of diabetes-related complications. Working age was assumed to be 20-65 years, with an average annual income of SEK394,800 for men and SEK340,800 for women [41]. A working year was assumed to consist of 250 working days. Data on sick days due to various diabetes complications were obtained from a Danish registry data analysis that comprised 34,882 patients with diabetes [42]. If we were unable to determine the number of sick days, a conservative assumption was made that the number of sick days was 0 . The health economic model does not differentiate between sick days during the 'first' and 'subsequent' years for each condition; however, this was reported in the Danish study. We therefore used the 'subsequent years' values to ensure a conservative analysis, as these were consistently lower. The analysis used a human capital approach.

\subsection{Utilities}

Utility values for various diabetes-related complications used in this cost-effectiveness analysis were derived from published studies (Table 4). Utilities associated with treatment complexity and utilities associated with the short-term effects of changes in $\mathrm{HbA}_{1 \mathrm{c}}$ levels were derived from the results of a time trade-off (TTO) study carried out in Sweden, Denmark and the UK [43]. The disutility of blood glucose testing was obtained from a TTO study carried out in Sweden, the UK and Canada [44]. For the effect of weight loss, as measured by body mass index (BMI), we used the lower of the utility values found in published studies (-0.006) [45-47] for the main analysis and the value from the TTO study $(-0.021)$ in the sensitivity analysis. Data on the extent to which patients' perceived utility is affected by hypoglycaemia episodes were derived from results for Swedish patients with T2DM in an extensive web-based TTO study [48, 49].

\subsection{One-Way Sensitivity Analyses}

As the base case used non-smoking men to model the cost effectiveness of IDegLira, we performed sensitivity analyses on patient characteristics with risk equations that differ from those for non-smokers and men, i.e. smokers and women. Various other characteristics, such as a baseline $\mathrm{HbA}_{1 \mathrm{c}}$ of $9 \%$ and a baseline BMI of 25 and 35 were also modelled in sensitivity analyses to investigate their effects on the cost effectiveness of IDegLira. Other sensitivity analyses were performed for clinical endpoints $\left(\mathrm{HbA}_{1 \mathrm{c}}\right.$ drift for GLP-1 of $0.08 \%$, no difference in $\mathrm{HbA}_{1 \mathrm{c}}$, no difference in $\mathrm{HbA}_{1 \mathrm{c}}$ but different complexity of regimen, depending on the number of daily injections, half the difference in $\mathrm{HbA}_{1 \mathrm{c}}$, no difference in BMI, no difference in hypoglycaemia for insulin glargine/NPH insulin, lower efficacy for liraglutide $1.2 \mathrm{mg}$ ), costs (healthcare perspective and using the price of a higher dose of liraglutide) and patient utilities (impact of BMI using a utility value of -0.021 , no impact of complexity vs. basal-bolus). These analyses and the rationale for undertaking them are outlined in Tables S2-S4 in the ESM.

\subsection{Probabilistic Sensitivity Analyses}

Probabilistic sensitivity analyses (PSAs) were conducted to assess the cost effectiveness of IDegLira when uncertainty 
Table 3 Mean daily and total annual costs (Swedish krona) used in the analyses of patients with diabetes uncontrolled with basal insulin [34]

\begin{tabular}{|c|c|c|c|c|c|c|c|}
\hline & IDegLira & $\begin{array}{l}\text { Insulin } \\
\text { glargine }\end{array}$ & $\begin{array}{l}\text { NPH } \\
\text { insulin }\end{array}$ & $\begin{array}{l}\text { Insulin aspart }(3 \times) \\
\text { added to insulin } \\
\text { glargine }\end{array}$ & $\begin{array}{l}\text { Insulin aspart }(3 \times) \\
\text { added to NPH insulin }\end{array}$ & $\begin{array}{l}\text { Liraglutide } 1.2 \mathrm{mg} \\
\text { added to insulin } \\
\text { glargine }\end{array}$ & $\begin{array}{l}\text { Liraglutide } 1.2 \mathrm{mg} \\
\text { added to NPH insulin }\end{array}$ \\
\hline \multicolumn{8}{|l|}{ Treatments } \\
\hline IDegLira & 50.42 & - & - & - & - & - & - \\
\hline Liraglutide & - & - & - & - & - & $33.36^{\mathrm{c}}$ & $33.36^{\mathrm{c}}$ \\
\hline $\begin{array}{l}\text { Basal } \\
\text { insulin }\end{array}$ & - & 22.26 & 9.98 & 24.57 & 11.02 & 12.97 & 5.81 \\
\hline $\begin{array}{l}\text { Prandial } \\
\text { insulin }\end{array}$ & - & - & - & 12.80 & 12.80 & - & - \\
\hline Metformin & 0.66 & 0.66 & 0.66 & 0.66 & 0.66 & 0.66 & 0.66 \\
\hline \multicolumn{8}{|l|}{ Consumables } \\
\hline Needles ${ }^{\mathrm{b}, \mathrm{d}}$ & 0.69 & 0.69 & 0.69 & $2.76^{\mathrm{e}}$ & $2.76^{\mathrm{e}}$ & $1.38^{\mathrm{f}}$ & $1.38^{\mathrm{f}}$ \\
\hline Test strips $^{\mathrm{g}}$ & 2.34 & 2.34 & 2.34 & $9.35^{\mathrm{h}}$ & $9.35^{\mathrm{h}}$ & 2.34 & 2.34 \\
\hline Lancets $^{\mathrm{i}}$ & 0.24 & 0.24 & 0.24 & $0.96^{\mathrm{j}}$ & $0.96^{\mathrm{j}}$ & 0.24 & 0.24 \\
\hline \multicolumn{8}{|l|}{ Total costs } \\
\hline $\begin{array}{l}\text { Total daily } \\
\text { cost }\end{array}$ & 54.35 & 26.19 & 13.91 & 51.11 & 37.55 & 50.95 & 43.79 \\
\hline $\begin{array}{l}\text { Total } \\
\text { annual cost } \\
\text { (SEK) }\end{array}$ & 19,850 & 9565 & 5080 & 18,689 & 13,722 & 18,608 & 15,994 \\
\hline
\end{tabular}

IDegLira insulin degludec liraglutide, NPH neutral protamine Hagedorn, PRP pharmacy retail price, SEK Swedish krona, TLV Tandvårds- och läkemedelsförmånsverket (Swedish Dental and Pharmaceutical Benefits Agency), VAT value-added tax

${ }^{\text {a }}$ Prices were obtained from the TLV price database on 5 September 2014

b The cost of needles were conservatively based on the PRP excluding VAT for the lowest-priced needles on the TLV website [34]; use was based on the number of injections

${ }^{\mathrm{c}}$ Expressed as the cost of liraglutide $1.2 \mathrm{mg}$ calculated based on the PRP (TLV) of liraglutide $54 \mathrm{mg}$ (Victoza ${ }^{\circledR}$ )

${ }^{\mathrm{d}}$ Expressed as the cost per unit calculated based on the PRP (TLV) of a 100 pack of I-Fine S $6 \mathrm{~mm} 31 \mathrm{G}$ needles (NordicInfu Care AB) unless otherwise stated

${ }^{\text {e }}$ Expressed as the cost of 4 units calculated based on the PRP (TLV) of a 100 pack of I-Fine S 6 mm 31 G needles (NordicInfu Care AB)

${ }^{\mathrm{f}}$ Expressed as the cost of 2 units calculated based on the PRP (TLV) of a 100 pack of I-Fine S $6 \mathrm{~mm} 31 \mathrm{G}$ needles (NordicInfu Care AB)

g Expressed as the cost per unit calculated based on the PRP (TLV) of a 50 pack of Wellion Luna test strips (Medtrust Sweden AB) unless otherwise stated

${ }^{\mathrm{h}}$ Expressed as the cost of 4 units calculated based on the PRP (TLV) of a 50 pack of Wellion Luna test strips (Medtrust Sweden AB)

${ }^{\mathrm{i}}$ Expressed as the cost per unit calculated based on the PRP (TLV) of a 200 pack of lancets (NordicInfu Care AB) unless otherwise stated

${ }^{\mathrm{j}}$ Expressed as the cost of 4 units calculated based on the PRP (TLV) of a 200 pack of lancets (NordicInfu Care AB)

of input variables were examined simultaneously. The absolute treatment effect on the $\mathrm{HbA}_{1 \mathrm{c}}$ level, the annual absolute drift of the $\mathrm{HbA}_{1 \mathrm{c}}$ level, $\mathrm{HbA}_{1 \mathrm{c}}$, initial absolute treatment effects on other biomarker levels and absolute drift of the other biomarker levels were varied using a normal distribution. To avoid negative values, event rates for hypoglycemia and other adverse events were varied using a log-normal distribution. Standard errors (SEs) of variables were used in the analyses where available (Table S3 in the ESM). If the SE of a variable was not available, assumptions were made (Table S3 in the ESM). All assumptions were made in consultation with TLV in conjunction with the reimbursement application of IDegLira. Each simulation employed 500 iterations.

\section{Results}

Table 5 outlines the cost per QALY gained in each of the main analyses, rounded to the nearest full hundred. All results are below SEK70,100 per QALY, suggesting that IDegLira is a cost-effective treatment option compared with the other six treatment options for patients with T2DM uncontrolled with basal insulin treatments.

\subsection{IDegLira Versus Basal Insulin}

The analysis of IDegLira versus up-titrated basal insulin in patients who had not achieved $\mathrm{HbA}_{1 \mathrm{c}}$ control with basal insulin showed a QALY difference of 0.97 compared with 
Table 4 Impact of patient demographics, clinical factors, treatment complexity and complications on patient utilities used in the analysis

\begin{tabular}{|c|c|c|}
\hline Characteristic & Utility score & References \\
\hline \multicolumn{3}{|l|}{ Demographics } \\
\hline Diabetes diagnosis & 0.817 & [41] \\
\hline Age (per 10 years) & -0.024 & {$[42]$} \\
\hline Sex (female) & -0.056 & [41] \\
\hline Duration of diabetes (per 10 years) & -0.010 & [41] \\
\hline \multicolumn{3}{|l|}{ Clinical factors } \\
\hline $\mathrm{HbA}_{1 \mathrm{c}}(\%)$ & -0.025 & {$[55]$} \\
\hline BMI $\left(\mathrm{kg} / \mathrm{m}^{2}\right)$ & -0.006 & {$[41,42]$} \\
\hline Mild daytime hypoglycaemia & -0.00449 & {$[44,45]$} \\
\hline Severe daytime hypoglycaemia & -0.05250 & {$[44,45]$} \\
\hline \multicolumn{3}{|l|}{ Impact of treatment complexity } \\
\hline $\begin{array}{l}\text { One injection/day vs. two injections at the same } \\
\text { time/day (IDegLira vs. GLP-1 added to basal insulin) }\end{array}$ & $0.015^{\mathrm{a}}$ & {$[55]$} \\
\hline $\begin{array}{l}\text { One injection/day vs. four injections/day including } \\
\text { planning (IDegLira vs. basal-bolus) }\end{array}$ & 0.109 & {$[55]$} \\
\hline \multicolumn{3}{|l|}{ Complications } \\
\hline \multicolumn{3}{|l|}{ Retinopathy } \\
\hline Non-proliferative retinopathy & -0.012 & [41] \\
\hline Proliferative retinopathy & -0.012 & [41] \\
\hline Macular oedema & -0.012 & [41] \\
\hline Severe visual impairment & -0.057 & [41] \\
\hline \multicolumn{3}{|l|}{ Neuropathy } \\
\hline Symptomatic neuropathy & -0.084 & [42] \\
\hline Peripheral vascular disease & -0.061 & [42] \\
\hline Amputation & -0.272 & {$[42]$} \\
\hline \multicolumn{3}{|l|}{ Nephropathy } \\
\hline Microalbuminuria & 0.000 & [42] \\
\hline Clinical nephropathy & -0.048 & [42] \\
\hline Kidney disease, uraemia stage & -0.175 & {$[42]$} \\
\hline \multicolumn{3}{|l|}{ Macrovascular complications } \\
\hline Ischaemic heart disease & -0.052 & [41] \\
\hline Myocardial infarction & -0.022 & [41] \\
\hline Stroke & -0.111 & {$[41]$} \\
\hline Heart failure & -0.082 & [41] \\
\hline
\end{tabular}

$B M I$ body mass index, GLP-1 glucagon-like peptide-1, $H b A_{l c}$ glycated haemoglobin, IDegLira insulin degludec liraglutide, $k g$ kilogrammes

${ }^{a}$ This difference was not significant in the analysis of Swedish patients and has therefore not been included in the analyses. However, the difference was significant in the analysis of Danish and British subjects, which included more subjects both insulin glargine and NPH insulin. IDegLira was more expensive, as shown by differences in treatment costs of SEK65,000 and 106,000 compared with insulin glargine and NPH insulin, respectively. However, the cost of complications was higher in the groups receiving up-titrated basal insulin, which meant the overall cost difference dropped to SEK28,000 and 68,000 compared with insulin glargine and NPH insulin, respectively. The greatest savings with IDegLira were seen in the costs of nephropathy and stroke. Patients using IDegLira switched to basal- bolus therapy after 12 years in the model simulation. The corresponding period in the basal insulin arm was 7 years.

These results give an ICER (cost per QALY gained) of SEK28,000 compared with insulin glargine and SEK70,000 compared with NPH insulin, with the only differences between insulin glargine and NPH insulin being the price and rate of hypoglycaemia.

The only sensitivity analysis that had any appreciable effect on the result were those that involved $\mathrm{HbA}_{1 \mathrm{c}}$. The analysis in which the $\mathrm{HbA}_{1 \mathrm{c}}$ drift during treatment with 
Table 5 Summary of base-case analysis results in costs (Swedish krona) per qualityadjusted life-year gained for each comparator ${ }^{\mathrm{a}}$

\begin{tabular}{llrll}
\hline Treatment A & Treatment B & $\Delta$ Costs & $\Delta$ QALYs & Cost per QALY \\
\hline IDegLira & Insulin glargine & 27,700 & 0.97 & 28,400 \\
IDegLira & NPH insulin & 68,400 & 0.97 & 70,100 \\
IDegLira & Insulin aspart added to insulin glargine & $-115,200$ & 2.14 & Dominant \\
IDegLira & Insulin aspart added to NPH insulin & $-47,200$ & 2.14 & Dominant \\
IDegLira & Liraglutide 1.2 mg added to insulin glargine & -3500 & 0.40 & Dominant \\
IDegLira & Liraglutide 1.2 mg added to NPH insulin & 24,000 & 0.40 & 60,000 \\
\hline
\end{tabular}

$\Delta$ difference operator, IDegLira insulin degludec liraglutide, NPH neutral protamine Hagedorn, $Q A L Y$ quality-adjusted life-year, SEK Swedish krona

a At the time of manuscript submission, the SEK to £ and SEK to $€$ exchange rate was 0.086918 and 0.102420 , respectively. For instance, SEK1000 $=£ 86.91$ or $€ 1024.20$ [60]
GLP-1 receptor analogue was set to $0.08 \%$ [50] instead of $0.15 \%[51,52]$ allowed patients to continue receiving this treatment for 21 years-instead of 12 years as in the main analysis-before triggering the switch to basal-bolus. This suggests IDegLira is dominant compared with insulin glargine, and the overall cost per QALY dropped to SEK39,000 compared with NPH insulin (Table S4 in the ESM). If the difference in $\mathrm{HbA}_{1 \mathrm{c}}$ reduction was ignored altogether, the cost per QALY rose to SEK332,000 and 484,000 , respectively. If, instead, the difference in $\mathrm{HbA}_{1 \mathrm{c}}$ reduction was assumed to be halved, the cost per QALY came to SEK92,000 and 156,000, respectively.

The cost-effectiveness acceptability curve resulting from the PSA of IDegLira versus NPH insulin and insulin glargine (Figs. S2 and S3 in the ESM, respectively) shows that, for a willingness-to-pay threshold of SEK300,000 per QALY, the probability of IDegLira being cost effective was $100 \%$ in both cases.

\subsection{IDegLira Versus Basal-Bolus Insulin}

Analyses of IDegLira versus basal-bolus, in patients with T2DM uncontrolled with basal insulin therapy, were performed with insulin aspart added on to both insulin glargine and NPH insulin as basal insulins. The only difference between these analyses was the price of the basal insulin, assuming identical clinical effects. Patients using IDegLira switched to basal-bolus therapy after 12 years. Since the comparator treatment was basal-bolus therapy from the start, patients in this arm continued to receive this treatment throughout the duration of the analysis period.

The difference in QALYs was 2.13 when compared with either insulin glargine or NPH insulin and consisted mainly of a difference in quality of life as a result of fewer complications, fewer hypoglycaemia episodes and less complex treatment. The cost of medication (treatment cost) was SEK18,000 higher with IDegLira than with insulin aspart added to insulin glargine. However, the cost of long-term complications was considerably higher with basal-bolus therapy, which resulted in the overall cost associated with IDegLira being SEK115,000 lower than with insulin aspart added to insulin glargine, suggesting that the IDegLira treatment was dominant (superior in terms of QALYs and cheaper). The treatment cost was SEK60,000 higher with IDegLira than with insulin aspart added to NPH insulin. However, when accounting for the cost of complications, the overall cost of IDegLira was SEK47,000 lower, with IDegLira again being dominant.

Similar results were seen in all sensitivity analyses (Table S4 in the ESM). Furthermore, the cost-effectiveness acceptability curves for insulin aspart added to NPH insulin (Fig. S4 in the ESM) and insulin aspart added to insulin glargine (Fig. S5 in the ESM) show that, at a willingnessto-pay threshold of SEK300,000 per QALY gained, the probability that IDegLira is cost effective was $100 \%$ in both cases.

\subsection{IDegLira Versus Basal Insulin + Liraglutide}

The analyses of IDegLira versus liraglutide $1.2 \mathrm{mg}$ added to basal insulin in patients with T2DM uncontrolled with basal insulin were performed with both insulin glargine and NPH insulin as the basal insulin comparator. The lower dose of liraglutide $1.2 \mathrm{mg}$ instead of $1.8 \mathrm{mg}$ was used in the model as it is more common in Sweden than the higher dose. The difference in QALYs was 0.40 and consisted mainly of a difference in quality of life due to fewer complications, fewer hypoglycaemia episodes and less complex treatment in the IDegLira group. Patients using IDegLira switched treatment after 12 years, whereas patients treated with liraglutide added to basal insulin switched after 9 years in the model simulation.

In the analysis versus liraglutide added to insulin glargine, the overall cost associated with IDegLira was SEK3500 lower than with liraglutide added to insulin glargine, suggesting that IDegLira treatment was dominant. The ICER was SEK60,000 in the analysis versus liraglutide added to NPH insulin. 
The majority of the sensitivity analyses provided results that were only marginally different from those of the main analysis. Ignoring the difference in $\mathrm{HbA}_{1 \mathrm{c}}$ meant there was no efficacy difference between treatments, whereas the price of the liraglutide added to basal insulin was lower. When we assumed the difference in $\mathrm{HbA}_{1 \mathrm{c}}$ reduction was half of that reported in the ITC, the cost per QALY came to SEK30,000 and 149,000, respectively, suggesting that $\mathrm{HbA}_{1 \mathrm{c}}$ reduction is the main driver of the results.

Where the difference in $\mathrm{HbA}_{1 \mathrm{c}}$ was disregarded but the non-significant complexity utility difference was included, the cost per QALY was SEK79,000 and 247,000, respectively, compared with liraglutide added to insulin glargine and NPH insulin. In addition, a sensitivity analysis was performed with the price of liraglutide $1.8 \mathrm{mg}$ instead of $1.2 \mathrm{mg}$ in the comparator arm. The rationale for this was that the clinical comparison was based on the higher dose. These analyses showed that IDegLira was dominant for liraglutide added on to both NPH and insulin glargine (Table S4 in the ESM).

PSAs further confirmed the results of the base case, with IDegLira displaying a lower cost per QALY than liraglutide added to NPH insulin (SEK55,654 vs. 60,000), while still being dominant compared with liraglutide added to insulin glargine. The cost-effectiveness acceptability curves (Figs. S6 and S7 in the ESM) show that, for a willingness-to-pay threshold of SEK300,000, the estimated probability that IDegLira is cost effective compared with liraglutide added to NPH insulin and liraglutide added to insulin glargine was 99 and $100 \%$, respectively.

\section{Discussion}

We have demonstrated that IDegLira may be a cost-effective treatment compared with the most commonly used treatment options for patients with T2DM uncontrolled with basal insulin. The analyses show that IDegLira is either dominant or has a cost-per-QALY below SEK70,100, which is deemed to be well below the willingness-to-pay threshold in Sweden [23].

The difference in $\mathrm{HbA}_{1 \mathrm{c}}$ reduction is driving the result (as a reduction in $\mathrm{HbA}_{1 \mathrm{c}}$ results in fewer complications and associated costs), but even if the difference is only half of that observed in the ITC, IDegLira remains cost effective in all comparisons (the Swedish National Board of Health and Welfare generally view an ICER of SEK100,000-500,000 as moderate) [23].

To our knowledge, the model used here is the only T2DM model developed for the Swedish population that includes Swedish macrovascular risk functions, with the majority of quality-of-life weights also being obtained from Swedish patients with T2DM [24].
The utility values for severe and non-severe hypoglycaemia used in the model are low and thus did not influence the results of the analysis. The model also allows the treatment to realistically follow disease progression. The external validation of the model was tested by simulating 12 clinical trials (both interventional and non-interventional) and comparing 167 predicted microvascular, macrovascular and mortality outcomes with those observed in the actual trials [24]. Moreover, the model has been used for several analyses, both in health economic publications $[40,45]$ and in the development of new national diabetes guidelines [6].

The analyses were based on an ITC of clinical studies [27] because, to date, the only clinical trials of IDegLira in patients with diabetes uncontrolled with basal insulin (DUAL $^{\mathrm{TM}}$ II and DUAL ${ }^{\mathrm{TM}} \mathrm{V}$ ) are comparative studies of insulin degludec and liraglutide. Only DUAL ${ }^{\mathrm{TM}}$ II results were included because the DUAL ${ }^{\mathrm{TM}} \mathrm{V}$ trial was ongoing at the time of the ITC. Nonetheless, the results of the ITC enabled a comprehensive analysis in which IDegLira was compared with all relevant treatment options. The ITC was performed according to best practice based on available data. In the clinical studies included in the ITC, liraglutide was used at a dose of $1.8 \mathrm{mg}$ instead of $1.2 \mathrm{mg}$, which is the more common dose in Sweden. Given the indirect nature of such a comparative method, this could be considered a limitation of the economic evaluation. However, considering the paucity of head-to-head clinical trial data, these types of approaches have become increasingly accepted and recommended by health technology assessment bodies across Europe [22, 53-55]. Furthermore, the results of the same ITC were used in a previous economic evaluation of IDegLira in patients with diabetes uncontrolled with basal insulin in a UK setting [56]. The use of clinical trial data, rather than observational real-world data, can also be considered a limitation of the model. When considering the stringent nature of clinical trials, it can be assumed that the clinical benefits of IDegLira would not fully translate in the real world due to non-adherence to treatment. While there is no way of assessing how clinical practice differs from a clinical trial setting in the absence of observational data, it is possible that the benefits of IDegLira might have been overestimated. Further limitations associated with the ITC are discussed in detail in Freemantle et al. [27].

As with any economic evaluation of long-term chronic diseases, another limitation of our analysis is the use of short-term clinical data to simulate the course of the disease on a 40-year time horizon. However, in the absence of long-term clinical data, the use of a simulation model based on clinical assumptions and long-term risk equations is arguably the most appropriate approach to assess the cost effectiveness of IDegLira and inform healthcare decisions. 
While the use of assumptions in health economic modelling tends to introduce a degree of uncertainty to the analyses, we have tried to minimise this by performing sensitivity analyses and, where possible, using conservative assumptions. For instance, the clinical data for NPH insulin were conservatively assumed to be the same as for insulin glargine in all combinations apart from the hypoglycaemia rates in the comparisons with up-titrated basal insulin only. These hypoglycaemia rates were based on a meta-analysis comparing hypoglycaemia rates of insulin glargine and NPH insulin [33]. Because data comparing hypoglycaemia levels between insulin glargine and NPH insulin in combination with insulin aspart or liraglutide were lacking, we conservatively assumed that the hypoglycaemia rates were the same for these combinations. Therefore, the main differentiating factor between these insulins in the analysis was the lower cost of NPH insulin. As we used clinical data from the ITC in our analyses, together with the prices of the more common and cheaper insulin options, our analyses are more conservative. Nonetheless, IDegLira was either dominant or cost effective (i.e. the cost per QALY was lower than SEK100,000) in all sensitivity analyses versus all the comparators. Similar results were obtained from a UK perspective using the IMS Health CORE Diabetes Model, where IDegLira was demonstrated to be cost effective [56, 57], which further demonstrates the reliability of the Swedish IHE Cohort Model of Type 2 Diabetes.

In our analysis, treatment intensification was based on an assumption in which we endeavoured to reflect real life. We assumed that treatment would be intensified at a level where the physician and patient consider the patient's $\mathrm{HbA}_{1 \mathrm{c}}$ to be too high. For this reason, we deemed it logical to use the same $\mathrm{HbA}_{1 \mathrm{c}}$ level both for initiating IDegLira and later on for switching to basalbolus therapy.

Utility scores were largely based on studies performed on Swedish patients with T2DM. Several of these utilities have been used previously, whereas others (patient utility relative to $\mathrm{HbA}_{1 \mathrm{c}}$ reduction and treatment complexity, respectively) were developed specifically for the purpose of this study [58]. The utility score of $\mathrm{HbA}_{1 \mathrm{c}}$ reduction we used is very close to an equivalent score obtained for type 1 diabetes mellitus [59]. The utility score of treatment complexity may seem high compared with basal-bolus therapy; however, considering the extent to which such a complex regimen impacts on the patient's everyday life, with four daily injections using two different pen devices as well as constant planning of doses and meals, this is not surprising. In addition, we performed a sensitivity analysis in which this utility score was excluded, which showed that its impact on the outcome was marginal and did not change the overall conclusion.

\section{Conclusion}

Based on the present findings, ths study has demonstrated that IDegLira may be cost effective for the treatment of patients with T2DM that is uncontrolled with basal insulin therapy in Sweden. In all analyses, where IDegLira was compared with up-titrated basal insulin, basal-bolus insulin or a GLP-1 agonist added to basal insulin, IDegLira was either cost effective, with an ICER of SEK70,000 or lower (vs. basal insulin up-titration or vs. adding GLP1 to basal insulin), or both more effective and cost saving (vs. basalbolus regimens). Sensitivity analyses show that the results are stable and driven by the difference in $\mathrm{HbA}_{1 \mathrm{c}}$ reduction between treatments.

Author contributions Both authors contributed to the study design, modelling, data interpretation and review and editing of the manuscript.

\section{Compliance with Ethical Standards}

Funding This study was funded by Novo Nordisk Scandinavia AB, the manufacturer of IDegLira.

Conflict of interest Åsa Ericsson is an employee of Novo Nordisk Scandinavia AB. Adam Lundqvist is an employee at IHE and declares no conflicts of interest.

Open Access This article is distributed under the terms of the Creative Commons Attribution-NonCommercial 4.0 International License (http://creativecommons.org/licenses/by-nc/4.0/), which permits any noncommercial use, distribution, and reproduction in any medium, provided you give appropriate credit to the original author(s) and the source, provide a link to the Creative Commons license, and indicate if changes were made.

\section{References}

1. Stratton IM, Adler AI, Neil HAW, Matthews DR, Manley SE, Cull CA, et al. Association of glycaemia with macrovascular and microvascular complications of type 2 diabetes (UKPDS 35): prospective observational study. BMJ. 2000;321(7258):405-12.

2. American Diabetes Association. Standards of medical care in diabetes: 2008. Diabetes Care. 2008;31(Suppl 1):S12-54.

3. Socialstyrelsen. Nationella riktlinjer för diabetesvården 2010 Stöd för styrning och ledning 2010. http://www.socialstyrelsen. se/. Accessed 22 Dec 2016.

4. International Diabetes Federation. Global guideline for type 2 diabetes 2012. https://www.idf.org/global-guideline-type-2diabetes-2012. Accessed 22 Dec 2016.

5. National Diabetes Register. NDR Statistik. https://ndrstatistik. registercentrum.se/ . Accessed 22 Dec 2016.

6. Socialstyrelsen. Nationella riktlinjer för diabetesvård: Stöd för styrning och ledning: Preliminär version 2014. http://www. socialstyrelsen.se/Lists/Artikelkatalog/Attachments/19470/20146-19.pdf. Accessed 22 Dec 2016.

7. National Diabetes Register (NDR). Årsrapport, 2013 års resultat 2013. https://www.ndr.nu/pdfs/Arsrapport_NDR_2013.pdf. Accessed 22 Dec 2016 
8. Cryer PE, Davis SN, Shamoon H. Hypoglycemia in diabetes. Diabetes Care. 2003;26(6):1902-12.

9. Frier BM. How hypoglycaemia can affect the life of a person with diabetes. Diabetes Metab Res. 2008;24(2):87-92.

10. Ostenson CG, Geelhoed-Duijvestijn P, Lahtela J, Weitgasser R, Markert Jensen M, Pedersen-Bjergaard U. Self-reported non-severe hypoglycaemic events in Europe. Diabet Med. 2014;31(1):92-101.

11. Östenson CG, Geelhoed-Duijvestijn PHLM, Jensen MM, Pedersen-Bjergaard U. DB4 patient-reported hypoglycaemia in realworld settings in seven European countries. Value Health. 2012;15(7):A277.

12. Khunti K, et al., editors. Hypoglycaemia among insulin-treated patients with diabetes: an international retrospective and prospective study of 3832 patients. World Diabetes Congress, 2-6 December 2013, Melbourne, Australia.

13. Jönsson L, Bolinder B, Lundkvist J. Cost of hypoglycemia in patients with Type 2 diabetes in Sweden. Value Health. 2006;9(3):193-8.

14. UK Prospective Diabetes Study (UKPDS) Group. Intensive bloodglucose control with sulphonylureas or insulin compared with conventional treatment and risk of complications in patients with type 2 diabetes (UKPDS 33. Lancet. 1998;352(9131):837-53.

15. Eeg-Olofsson K, Cederholm J, Nilsson PM, Zethelius B, Nunez $\mathrm{L}$, Gudbjornsdottir S, et al. Risk of cardiovascular disease and mortality in overweight and obese patients with type 2 diabetes: an observational study in 13,087 patients. Diabetologia. 2009;52(1):65-73.

16. Odegaard K, Borg S, Persson U, Svensson M. The Swedish cost burden of overweight and obesity-evaluated with the PAR approach and a statistical modelling approach. Int J Pediatr Obes. 2008;3(Suppl 1):51-7.

17. Peyrot M, Barnett AH, Meneghini LF, Schumm-Draeger PM. Insulin adherence behaviours and barriers in the multinational Global Attitudes of Patients and Physicians in Insulin Therapy study. Diabet Med. 2012;29(5):682-9.

18. Dushay J, Abrahamson MJ. Insulin therapy for type 2 diabetes: making it work. J Fam Pract. 2010;59(4):E1-8.

19. Inzucchi SE, Bergenstal RM, Buse JB, Diamant M, Ferrannini E, Nauck M, et al. Management of hyperglycemia in type 2 diabetes: a patient-centered approach position statement of the American Diabetes Association (ADA) and the European Association for the Study of Diabetes (EASD). Diabetes Care. 2012;35(6):1364-79.

20. Socialstyrelsen. National Guidelines for Diabetes Care. http:// www.socialstyrelsen.se/Lists/Artikelkatalog/Attachments/19803/ 2015-4-12.pdf. Accessed 22 Dec 2016.

21. Inzucchi SE, Bergenstal RM, Buse JB, Diamant M, Ferrannini E, Nauck M, et al. Management of hyperglycemia in type 2 diabetes, 2015: a patient-centered approach: update to a position statement of the American Diabetes Association and the European Association for the Study of Diabetes. Diabetes Care. 2015;38(1): $140-9$.

22. Tandvårds- och läkemedelsförmånsverket (TLV). General guidelines for economic evaluations from the Pharmaceutical Benefits Board (LFNAR 2003:2) 2003. http://www.tlv.se/Upload/ English/Guidelines-for-economic-evaluations-LFNAR-2003-2. pdf. Accessed 22 Dec 2016.

23. Socialstyrelsen. Nationella riktlinjer för diabetesvård. http:// www.socialstyrelsen.se/SiteCollectionDocuments/nr-diabetes-me todbeskrivning.pdf. Accessed 22 Dec 2015.

24. Lundqvist A, Steen Carlsson K, Johansen P, Andersson E, Willis M. Validation of the IHE cohort model of Type 2 diabetes and the impact of choice of macrovascular risk equations. PloS One. 2014;9(10):e110235.

25. Ahmad Kiadaliri A, Gerdtham UG, Nilsson P, Eliasson B, Gudbjornsdottir S, Carlsson KS. Towards renewed health economic simulation of type 2 diabetes: risk equations for first and second cardiovascular events from Swedish register data. PloS One. 2013;8(5):e62650.

26. Hayes AJ, Leal J, Gray AM, Holman RR, Clarke PM. UKPDS outcomes model 2: a new version of a model to simulate lifetime health outcomes of patients with type 2 diabetes mellitus using data from the 30 year United Kingdom Prospective Diabetes Study: UKPDS 82. Diabetologia. 2013;56(9):1925-33.

27. Freemantle N, Mamdani M, Vilsboll T, Kongso JH, Kvist K, Bain SC. IDegLira versus alternative intensification strategies in patients with Type 2 diabetes inadequately controlled on basal insulin therapy. Diabetes Ther. 2015;6(4):573-91.

28. Buse JB, Vilsboll T, Thurman J, Blevins TC, Langbakke IH, Bottcher SG, et al. Contribution of liraglutide in the fixed-ratio combination of insulin degludec and liraglutide (IDegLira). Diabetes Care. 2014;37(11):2926-33.

29. Ahmann AJ, et al., Efficacy and safety of liraglutide vs. placebo when added to basal insulin analogs in patients with type 2 diabetes (LIRAADD2BASAL): 331-OR. Diabetes. 2014;63(Suppl 1):1056-64.

30. Garber AJ, King AB, Del Prato S, Sreenan S, Balci MK, MunozTorres $\mathrm{M}$, et al. Insulin degludec, an ultra-longacting basal insulin, versus insulin glargine in basal-bolus treatment with mealtime insulin aspart in type 2 diabetes (BEGIN Basal-Bolus Type 2): a phase 3, randomised, open-label, treat-to-target noninferiority trial. Lancet. 2012;379(9825):1498-507.

31. Meneghini L, Atkin SL, Gough SC, Raz I, Blonde L, Shestakova $\mathrm{M}$, et al. The efficacy and safety of insulin degludec given in variable once-daily dosing intervals compared with insulin glargine and insulin degludec dosed at the same time daily: a 26-week, randomized, open-label, parallel-group, treat-to-target trial in individuals with type 2 diabetes. Diabetes Care. 2013;36(4):858-64.

32. ClinicalTrials.gov. Comparison of NN5401 With insulin glargine, both in combination with oral antidiabetic drugs, in subjects with type 2 diabetes $\left(\mathrm{BOOST}^{\mathrm{TM}}\right.$ ) 2015. https://clinicaltrials.gov/ct2/show/ results/NCT01045447?term=NCT01045447\&rank=1. Accessed 22 Dec 2016.

33. Tandvårds- och läkemedelsförmånsverket (TLV). Tresiba Tandvårds- och läkemedelsförmånsverket reimbursement application. 2013. http://www.tlv.se/upload/beslut_2013/bes130618-tresiba. pdf. Accessed 22 Dec 2016.

34. Socialstyrelsen. Diabetesvård—Rekommendationer, bedömningar och sammanfattning. 2015. http://www.socialstyrelsen.se/Lists/ Artikelkatalog/Attachments/19687/2015-2-1.pdf. Accessed 22 Dec 2016.

35. Moberg E. Diabetes. 2016. http://viss.nu/Handlaggning/ Vardprogram/Endokrina-organ/Diabetes/. Accessed 22 Dec 2016.

36. Statistics Sweden. CPI, indices for main groups, annual averages. http://www.scb.se/en_/Finding-statistics/Statistics-by-subject-area/ Prices-and-Consumption/Consumer-Price-Index/Consumer-PriceIndex-CPI/Aktuell-Pong/33779/Consumer-Price-Index-CPI/33907/. Accessed 22 Dec 2016.

37. Tandvårds - och läkemedelsförmånsverket (TLV). Databas för beslut 2014 [5 September]. http://www.tlv.se/beslut/. Accessed 22 Dec 2016.

38. Devries JH, Nattrass M, Pieber TR. Refining basal insulin therapy: what have we learned in the age of analogues? Diabetes Metab Res Rev. 2007;23(6):441-54.

39. Geelhoed-duijvestijn PHLM, Pedersen-bjergaard U, Jensen MM, Östenson CG. PDB47 effects of patient-reported non-severe hypoglycaemia on health care resource use and work-time loss in seven European countries. Value Health. 2012;15(7):A502.

40. Steen Carlsson K, Persson U. Cost-effectiveness of add-on treatments to metformin in a Swedish setting: liraglutide vs sulphonylurea or sitagplitin. J Med Econ. 2014;17(9):658-69. 
41. Statistics Sweden. Average monthly salary by sector 1992-2013. http://www.scb.se/en_/Finding-statistics/Statistics-by-subjectarea/Labour-market/Wages-salaries-and-labour-costs/Salarystructures-whole-economy/Aktuell-Pong/14374/149087/. Accessed 22 Dec 2016.

42. Sørensen J, Jon Plough U. The cost of diabetes-related complications: registry-based analysis of days absent from work. Econ Res Int. 2013;2013:8.

43. Evans M, Ridderstråle M, Jensen HH, Bøgelund M, Jensen MM, Ericsson $\AA$, et al., editors. PDB108: quantifying the short-term impact of changes in $\mathrm{HbA1c}$, weight and insulin regimen on health related quality-of-life. ISPOR 18th Annual European Congress, 2015, Milan, Italy.

44. Evans M, Jensen HH, Bogelund M, Gundgaard J, Chubb B, Khunti K. Flexible insulin dosing improves health-related quality-of-life (HRQoL): a time trade-off survey. J Med Econ. 2013;16(11):1357-65.

45. Kiadaliri A, Gerdtham U-G, Eliasson B, Gudbjörnsdottir S, Svensson A-M, Carlsson K. Health utilities of type 2 diabetesrelated complications: a cross-sectional study in Sweden. Int $\mathbf{J}$ Environ Res Public Health. 2014;11(5):4939-52.

46. Bagust A, Beale S. Modelling EuroQol health-related utility values for diabetic complications from CODE-2 data. Health Econ. 2005;14(3):217-30.

47. Lane S, Levy AR, Mukherjee J, Sambrook J, Tildesley H. The impact on utilities of differences in body weight among Canadian patients with type 2 diabetes. Curr Med Res Opin. 2014;30(7):1267-73.

48. Evans M, Khunti K, Mamdani M, editors. Health-related quality of life associated with daytime and nocturnal hypoglycemic events: a time trade-off survey oral presentation 135. American Diabetes Association 72nd Annual Scientific Sessions, 8-12 June 2012, Philadelphia, USA.

49. Evans M, Khunti K, Mamdani M, Galbo-Jorgensen CB, Gundgaard J, Bogelund M, et al. Health-related quality of life associated with daytime and nocturnal hypoglycaemic events: a time trade-off survey in five countries. Health Qual Life Outcomes. 2013;11:90.

50. Henry RR, et al., DURATION-1 extension: Efficacy and tolerability of exenatide once weekly (qw) over 6 years in patients with T2DM. Poster presentation 964-P. Presented at the American Diabetes Association 74nd Annual Scientific Sessions, San
Francisco; 13-17 June 2014. http://ada.scientificposters.com/ epsAbstractADA.cfm?id=8, 2014. Accessed 22 Dec 2016.

51. Turner R, Cull C, Holman R. United Kingdom Prospective Diabetes Study 17: a 9-year update of a randomized, controlled trial on the effect of improved metabolic control on complications in non-insulin-dependent diabetes mellitus. Ann Intern Med. 1996;124(1 Pt 2):136-45.

52. Ward AJ, Salas M, Caro JJ, Owens D. Health and economic impact of combining metformin with nateglinide to achieve glycemic control: comparison of the lifetime costs of complications in the UK. Cost Eff Resour Alloc. 2004;2(1):2.

53. National Institute for Health and Care Excellence (NICE). NICE DSU Technical support document 1: introduction to evidence synthesis for decision making 2012. http://www.nicedsu.org.uk/ TSD1\%20Introduction.final.08.05.12.pdf. Accessed 22 Dec 2016.

54. Institut fur Qualitat und Wirtschaftlichkeit im Gesundheitswesen (IQWiG). General methods 4.2. 2015. https://www.iqwig.de/ download/IQWiG_General_Methods_Version_\%204-2.pdf. Accessed 22 Dec 2016.

55. Haute Autorite de Sante (HAS). Choices in methods for economic evaluation 2012. http://www.has-sante.fr/portail/upload/ docs/application/pdf/2012-10/choices_in_methods_for_economic_ evaluation.pdf. Accessed 22 Dec 2016.

56. Davies MJ, Glah D, Chubb B, Konidaris G, McEwan P. Cost effectiveness of IDegLira vs. alternative basal insulin intensification therapies in patients with type 2 diabetes mellitus uncontrolled on basal insulin in a UK setting. PharmacoEconomics. 2016;34(9):953-66.

57. McEwan P, Foos V, Palmer JL, Lamotte M, Lloyd A, Grant D. Validation of the IMS CORE diabetes model. Value Health. 2014;17(6):714-24.

58. Ridderstråle M, Evans LM, Jensen HH, Bøgelund M, Jensen MM, Ericsson $\AA$, et al. Estimating the impact of changes in HbA1c, body weight and insulin injection regimen on health related quality-of-life: a time trade off study. Health Qual Life Outcomes. 2016;14(1):1-10.

59. McQueen RB, Ellis SL, Maahs DM, Anderson HD, Nair KV, Libby AM, et al. Association between glycated hemoglobin and health utility for type 1 diabetes. Patient. 2014;7(2):197-205.

60. X-Rates. Swedish krona historic exchange rates look-up 2016. http://www.X-rates.com/historical/?from $=$ SEK\&amount=1\&date =2016-11-24. Accessed 24 Nov 2016. 